\title{
OCCURRENCE, PERSISTENCE, AND EXPANSION OF SALTCEDAR (TAMARIX SPP.) POPULATIONS IN THE GREAT PLAINS OF MONTANA
}

\author{
Jason P. Sexton ${ }^{1,2}$, Anna Sala ${ }^{1,3}$, and Kevin Murray ${ }^{1}$
}

\begin{abstract}
Saltcedar (Tamarix spp.), a shrub native to Eurasia, is associated with major alterations to wetland and riparian systems in the southwestern United States. Since the 1960s saltcedar has been naturalized in northern states of the U.S. where its growth potential and impacts are not well known. Here, we describe the occurrence, age, size, and relative cover of saltcedar populations in several river basins in central eastern Montana, USA, to identify potential patterns of spread across the region and changes in individual populations as they age. Stands were aged according to the oldest saltcedar individuals and were sampled for dominant plant cover and soil properties. Multiple introductions appear to have occurred in Montana, with the oldest stands occurring on the Bighorn River in southern Montana. Saltcedar absolute and relative cover and stand area increased significantly with stand age, while native tree and shrub relative cover remained low across all stand ages. These results suggest that saltcedar stands establish where woody natives are not abundant and that they persist and expand over time. Although soil salinity remained constant, soil $\mathrm{pH}$ decreased with saltcedar stand age, indicating a possible effect of organic matter inputs. An analysis of annual wood increment of saltcedar and sandbar willow (a native with analogous growth form) stems along a latitudinal gradient showed that stem growth of both species did not differ significantly among regions. Stem growth decreased inversely with elevation for both species while growth responses to elevation did not differ between species. Our results show an increase in number of populations and continued viability of these populations. Mechanisms of saltcedar increases in this region are yet to be determined. Anthropogenic influences, such as saltcedar plantings, watershed alterations (e.g., river flow control), and habitat disturbances (e.g., cattle grazing or habitat clearing) may facilitate its spread in similar climates of the Great Plains.
\end{abstract}

Key words: Tamarix ramosissima, Tamarix chinensis, saltcedar, tamarisk, invasive status, nonnative distribution, cottonwood, willow, Great Plains, Montana, range margins.

Plant introductions have caused substantial losses of native diversity, alterations to ecosystem functions, and economic losses. The spread of introduced species at the margins of their new range, where invasive status is less certain, provides useful insights on the ecology of biological invasions and the potential for further spread. At novel range margins, introduced species should expand their range until they experience environmental (e.g., climate) and biological (e.g., competitive exclusion) barriers, similar to native distributional limits (Sykes et al. 1996). Here we examine the occurrence and expansion of populations of an introduced plant near its range margin and assess potential impacts normally ascribed to portions of its range where its status is "invasive."

Saltcedar (Tamarix ramosissima Ledeb., Tamarix chinensis Lour., and the hybrids between these species [Gaskin and Schaal 2002]) is a deciduous shrub native to Europe and
Asia that is widespread in riparian habitats of the western U.S. (Robinson 1965). Since the introduction of saltcedar in the 19th century (Brock 1994), it has been listed as an invasive species in many southwestern states (USDA and NRCS 2004). In the colder, northern margins of its distribution, including central eastern Montana, where it was introduced as late as the 1960s (Sexton 2000), saltcedar is less abundant and has a smaller stature (Brock 1994, Dixon and Johnson 1999, Lesica and Miles 2001).

While shorter growing seasons and colder temperatures in northern climates may limit saltcedar's growth potential, the wide distribution in its native range (Baum 1978) suggests that the species is highly plastic and adaptive. Consistent with this, saltcedar has been shown to exhibit high genetic variation within its North American range (Gaskin and Schaal 2002) and significant functional and genetic differentiation between latitudinal extremes in the western

\footnotetext{
${ }^{1}$ Division of Biological Sciences, University of Montana, Missoula, MT 59812.

${ }^{2}$ Present address: Graduate Group in Ecology, Department of Plant Sciences, University of California, Davis, CA 95616-8780.

${ }^{3}$ Corresponding author.
} 
U.S. (Sexton et al. 2002). These results suggest that saltcedar has the potential to expand its current introduced range.

In the southwestern U.S., saltcedar can alter important ecosystem properties by creating different environments than native dominant plants (Busch and Smith 1995, Sala et al. 1996, Cleverly et al. 1997, Smith et al. 1998, Kennedy and Hobbie 2004). In these systems saltcedar establishment has a negative impact on the cover of native vegetation (Cleverly et al. 1997), although flooding may mitigate this effect (Shafroth et al. 2002). In Montana, saltcedar grows poorly beneath stands of native woody riparian vegetation such as Populus spp. (Lesica and Miles 2001), which is consistent with its low seedling competitive ability and the hypothesis that it requires disturbed (natural or anthropomorphic) areas free from competitors for successful recruitment (Sher et al. 2002, Sher and Marshall 2003). However, whether or not establishment of saltcedar in disturbed sites constrains the establishment of native vegetation is not known.

Association with saltcedar and increased soil salinity has been shown at some sites (Busch and Smith 1995) but not others (Stromberg 1998b). Increases in percent clay beneath older saltcedar stands have also been documented in southern Arizona (Stromberg 1998b). Whether or not saltcedar alters soil properties at the limits of its introduced range is not known.

Here we document the occurrence of saltcedar populations in central eastern Montana and address the following questions: (1) On which watersheds is saltcedar found in central eastern Montana, and can a geographic pattern of spread be identified based on stand age? (2) Do saltcedar stands persist and increase in size as they get older? (3) Does saltcedar stem growth change across latitudes, and is this pattern similar to that of a native species of similar growth form? (4) Do vegetation and soil properties change as saltcedar stands age?

\section{Methods}

\section{Survey of Saltcedar Stands in Eastern Montana}

Presence of saltcedar was surveyed during the summer of 1998 at sites accessible by road along rivers of central eastern Montana. Saltcedar occurs in the Great Plains region of east- ern Montana within various riparian habitats of the Missouri River system (Pearce and Smith 2003), including the Yellowstone River and its major tributaries such as the Powder and Bighorn Rivers (Swenson et al. 1982). A total of 23 saltcedar stands, where saltcedar was present in variable quantities (from patches containing a few, scattered individuals to patches dominated by saltcedar), were sampled (Fig. 1, Table 1). Sites were not selected at random, but rather to uniformly represent the Great Plains watersheds drained by the Yellowstone River in central eastern Montana. We sampled 6 additional sites noted as "seedling beds," where only seedlings occurred on alluvial sandbars, for inclusion in soil and plant cover analyses. Depending on stand size, $1-3$ ten- $\mathrm{m}^{2}$ $(2 \times 5-\mathrm{m})$ plots were positioned randomly within the stand with the long axis perpendicular to the direction of river flow. We transformed absolute and relative cover (\%) estimates of living saltcedar, willow (Salix spp.), and plains cottonwood (Populus deltoides Marsh.) into the following cover scale as in Cleverly et al. (1997): $1 \leq 5 \%, 2=5 \%-15 \%, 3=15 \%-35 \%$, $4=35 \%-65 \%, 5=65 \%-85 \%, 6=85 \%-95 \%$, $7 \geq 95 \%$. Plot cover values were averaged to calculate mean stand values. We also measured the following physical characteristics for each stand: stand age, stand area $\left(\mathrm{m}^{2}\right)$ as estimated from stand length and width, and elevation (determined from topographic maps). Stand age was estimated by counting annual growth rings from root crowns of the estimated 3 largest (greatest height, number of stems, and basal stem diameter) saltcedar individuals found within the stand. Cross sections were collected by handsaw from each plant below the point at which stems diverged, and above the point at which roots diverged. "Expansion" in this study refers to increases in size of individual populations (stands). "Spread" refers to regional increases in population number.

\section{Soil Sampling}

Soil samples were collected from all sites $(n$ $=29$ ) to assess soil properties across differentaged stands. Within each $2 \times 5$-m plot, 10 soil cores $(7.5 \mathrm{~cm}$ depth and $2.54 \mathrm{~cm}$ diameter) were collected at random and analyzed for texture (percent sand, silt, and clay), electrical conductivity (EC), and $\mathrm{pH}$. We measured $\mathrm{pH}$ because it has been shown to vary with salinity (Buckman and Brady 1969). Samples from 


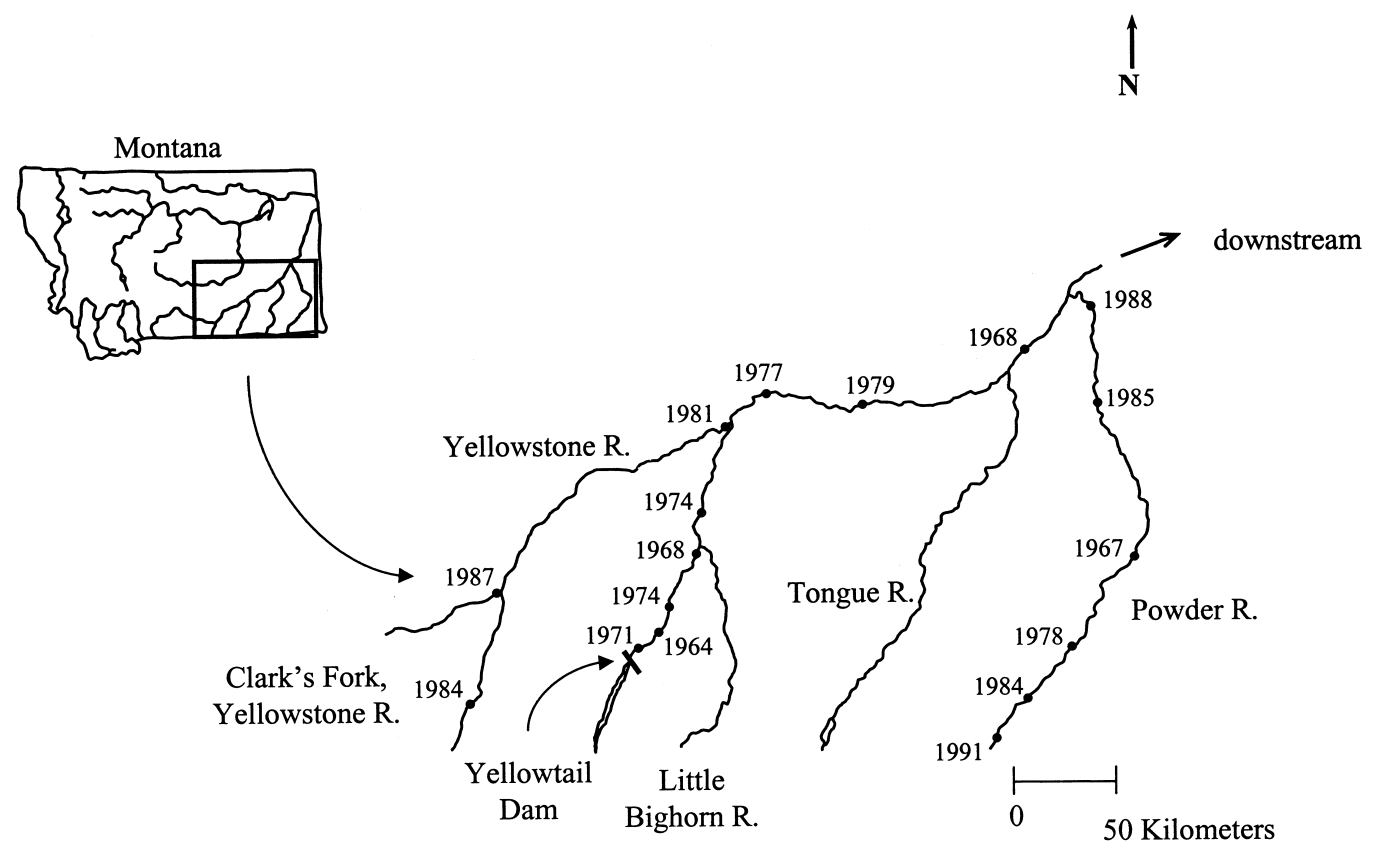

Bighorn R.

Fig. 1. Saltcedar study area in central eastern Montana showing sampling sites and estimated years of establishment of saltcedar stands.

each plot were combined and mixed, air-dried, and sieved to $2 \mathrm{~mm}$. We determined soil texture by hydrometer method (Gee and Bauder 1986). EC was measured using a Cole-Parmer conductivity meter. We measured $\mathrm{pH}$ with an Orian 710 meter equipped with a combination gel-filled electrode. Texture, EC, and $\mathrm{pH}$ values for each plot were pooled to obtain a stand average.

\section{Stem Growth}

During the summers of 1997 and 1998, we collected stem cross sections on low-gradient floodplains in Arizona, Nevada, Utah, Wyoming, and Montana where saltcedar was abundant and formed dense stands (Tables 1, 2). Across this latitudinal gradient, we chose at least 3 localities within each region (state), keeping elevation in each as similar as possible. Except for Montana (see below), we collected 30 stem samples at each locality to evenly represent the range of stem diameters present at the site. Stem samples from all localities within each region were pooled to represent regional stem growth. Stems of Montana saltcedar were randomly sampled from a pool of 1100 samples from 23 localities (Table 1) in eastern Montana that had been collected for a demographic dataset (Sexton 2000). Stems of sandbar willow (Salix exigua Nutt.), a native shrub with a ground-branching growth form similar to saltcedar, were sampled for comparison at sites where these species co-occurred (all but Arizona sites). Stem age was determined by counting annual growth rings. We collected fewer willow samples (maximum of 20 at each locality) as these plants were less abundant than saltcedar. Irregularly shaped or deformed stem samples were excluded from analyses. Climate data from meteorological stations with similar latitudes and elevations to field sites were obtained from Weather America (Garoogian 2001) for regression analyses (below).

\section{Data Analyses}

All data were screened and transformed when necessary to meet the assumptions of parametric analyses (Sokal and Rohlf 1995). Spearman's coefficient of rank correlation $\left(r_{s}\right)$ between stand age and elevation was used to detect directional saltcedar dispersal patterns separately within the Bighorn, Powder, and 
TABLE 1. Characteristics of Tamarix spp. stands in central eastern Montana. Unless listed, longitude/latitude was recorded at each site, not per individual stand within a site.

\begin{tabular}{|c|c|c|c|c|c|c|c|}
\hline Site \# & Stand & Watershed & Latitude & Longitude & $\begin{array}{l}\text { Elevation } \\
\quad(\mathrm{m})\end{array}$ & $\begin{array}{l}\text { Stand age } \\
\text { (years) }\end{array}$ & $\begin{array}{l}\text { Stand area } \\
\left(\mathrm{m}^{2}\right)\end{array}$ \\
\hline 1 & BHBH1 & Bighorn River & $45^{\circ} 25^{\prime} \mathrm{N}$ & $107^{\circ} 47^{\prime} \mathrm{W}$ & 944.4 & 31 & 358 \\
\hline “ & ВНВН2 & “ & “ & “ & “ & 34 & 544 \\
\hline 2 & BHGM1 & “ & $45^{\circ} 50.553^{\prime} \mathrm{N}$ & $107^{\circ} 35.235^{\prime} \mathrm{W}$ & 836.7 & 24 & 2230 \\
\hline “ & BHGM2 & “ & “ & “ & “ & 17 & 242 \\
\hline 3 & BHLM1 & “ & $46^{\circ} 08.436^{\prime} \mathrm{N}$ & $107^{\circ} 27.777^{\prime} \mathrm{W}$ & 795 & 24 & 437 \\
\hline “ & BHLM2 & “ & “ & " & “ & 1 & 176 \\
\hline “ & BHLM3 & “ & “ & “ & “ & 1 & 289 \\
\hline “ & BHLM4 & “ & “ & “ & “ & 21 & 372 \\
\hline 4 & BHML & “ & $45^{\circ} 31.5^{\prime} \mathrm{N}$ & $107^{\circ} 43.4^{\prime} \mathrm{W}$ & 897 & 24 & 260 \\
\hline 5 & BHTL & “ & $45^{\circ} 38.566^{\prime} \mathrm{N}$ & $107^{\circ} 39.492^{\prime} \mathrm{W}$ & 880.8 & 30 & 1696 \\
\hline 6 & BHTM & “ & $45^{\circ} 20.668^{\prime} \mathrm{N}$ & $107^{\circ} 52.668^{\prime} \mathrm{W}$ & 994.5 & 27 & 314 \\
\hline 7 & CYS & $\begin{array}{l}\text { Clark's Fork, } \\
\text { Yellowstone R. }\end{array}$ & $45^{\circ} 18.838^{\prime} \mathrm{N}$ & $108^{\circ} 54.639^{\prime} \mathrm{W}$ & 1086 & 14 & 15 \\
\hline 8 & PRBC & Powder R. & $45^{\circ} 11.863^{\prime} \mathrm{N}$ & $105^{\circ} 45.252^{\prime} \mathrm{W}$ & 965.7 & 14 & 300 \\
\hline 9 & PRBLM1 & “ & $45^{\circ} 20.865^{\prime} \mathrm{N}$ & $105^{\circ} 31.827^{\prime} \mathrm{W}$ & 903 & 20 & 246 \\
\hline “ & PRBLM2 & “ & $45^{\circ} 20.788^{\prime} \mathrm{N}$ & $105^{\circ} 31.938^{\prime} \mathrm{W}$ & “ & 11 & 448 \\
\hline “ & PRBLM3 & “ & $45^{\circ} 20.921^{\prime} \mathrm{N}$ & $105^{\circ} 31.387^{\prime} \mathrm{W}$ & “ & 4 & 147 \\
\hline 10 & PRF & “ & $45^{\circ} 42.000^{\prime} \mathrm{N}$ & $105^{\circ} 10.693^{\prime} \mathrm{W}$ & 855 & 31 & 1024 \\
\hline 11 & PRGR1 & “ & $46^{\circ} 28.387^{\prime} \mathrm{N}$ & $105^{\circ} 18.521^{\prime} \mathrm{W}$ & 681 & 13 & 125 \\
\hline “ & PRGR2 & “ & “ & " & “ & 1 & 155 \\
\hline 12 & PRT1 & “ & $46^{\circ} 44.409^{\prime} \mathrm{N}$ & $105^{\circ} 25.917^{\prime} \mathrm{W}$ & 674.1 & 1 & 150 \\
\hline “ & PRT2 & “ & “ & “ & “ & 10 & 100 \\
\hline “ & PRT3 & “ & “ & “ & “ & 1 & 200 \\
\hline 13 & PRWY & “ & $45^{\circ} 00.350^{\prime} \mathrm{N}$ & $105^{\circ} 53.993^{\prime} \mathrm{W}$ & 1032.6 & 7 & 270 \\
\hline 14 & YSC & Yellowstone R. & $46^{\circ} 08.421^{\prime} \mathrm{N}$ & $107^{\circ} 32.821^{\prime} \mathrm{W}$ & 840 & 17 & 198 \\
\hline 15 & YSDC & “ & $45^{\circ} 41.622^{\prime} \mathrm{N}$ & $108^{\circ} 38.434^{\prime} \mathrm{W}$ & 960 & 11 & 32 \\
\hline 16 & YSM & “ & $46^{\circ} 30.225^{\prime} \mathrm{N}$ & $105^{\circ} 44.128^{\prime} \mathrm{W}$ & 711.3 & 30 & 144 \\
\hline 17 & YSMB1 & “ & $46^{\circ} 15.429^{\prime} \mathrm{N}$ & $107^{\circ} 20.285^{\prime} \mathrm{W}$ & 810 & 21 & 20,574 \\
\hline “ & YSMB2 & “ & “ & “ & “ & 1 & 360 \\
\hline 18 & YSRR & “ & $46^{\circ} 15.909^{\prime} \mathrm{N}$ & $106^{\circ} 41.915^{\prime} \mathrm{W}$ & 758.7 & 19 & 115 \\
\hline
\end{tabular}

Yellowstone Rivers. We used linear regression analysis to describe and test the relationships between saltcedar stand age and estimated stand area, saltcedar cover, and soil parameters.

We analyzed stem growth data in 3 steps. First, least square means of regional stem diameter/age (stem growth) were plotted to detect latitudinal patterns in stem growth. Second, we analyzed data using analysis of variance (ANOVA) to test for regional differences in stem growth rates. In this model, stem diameter was the dependent variable, stem age a covariate, and state of origin (region) the independent variable. Third, we used ANOVA to test for effect of elevation on stem growth and species-specific differences in growth responses to elevation (interaction of species and elevation). In this model, stem diameter/age was the dependent variable, elevation a covariate, and species the independent variable. ANOVAs (ANCOVAs) were performed using General Linear Model in SYSTAT, version 10.

\section{RESUlTS}

\section{Stand Distribution and History}

Saltcedar was found on alluvial sandbars, channel banks, terraces, and islands along the Yellowstone River and its major tributaries (Fig. 1). The oldest individual saltcedar encountered in this study (34 years in 1998) was located at Bighorn Access on the Bighorn River (Table 1). Older stands were found mostly along the Bighorn River near Yellowtail Dam in Bighorn County, with some on the Powder and Yellowstone Rivers. Stand age correlated with elevation only on the Bighorn River where there was a positive relationship (Spearman correlation: $\left.r_{s}=0.675, P=0.050, n=9\right)$.

\section{Stand Dynamics}

Overall, older stands were larger $\left(r^{2}=0.276\right.$, $P=0.003$; Fig. 2) and had greater saltcedar absolute cover $\left(r^{2}=0.291, P=0.003\right.$; Fig. 3A). Because our criterion to select stands was the 
TABLE 2. Geographic and climate characteristics of localities where saltcedar and sandbar willow stems were collected. Saltcedar stems from Montana were sampled across localities in Table 1. Climate data are from meteorological stations (30-year averages listed in Weather America [Garoogian 2001]), with elevations and latitudes similar to localities. Mean temperatures are averages over the entire year.

\begin{tabular}{|c|c|c|c|c|c|c|}
\hline $\begin{array}{l}\text { State and } \\
\text { watershed }\end{array}$ & Latitude & Longitude & $\begin{array}{l}\text { Elevation } \\
(\mathrm{m})\end{array}$ & $\begin{array}{c}\text { Climate } \\
\text { center }\end{array}$ & $\begin{array}{c}\text { Mean } \\
\text { temp. }\left({ }^{\circ} \mathrm{C}\right)\end{array}$ & $\begin{array}{l}\text { Frost- } \\
\text { free days }\end{array}$ \\
\hline Montana & & & & Hysham, Treasure Co., MT & 8.33 & 194 \\
\hline Fort Peck Lake & $47^{\circ} 37.3^{\prime} \mathrm{N}$ & $106^{\circ} 11.5^{\prime} \mathrm{W}$ & 703 & & & \\
\hline Fort Peck Lake & $47^{\circ} 33.7^{\prime} \mathrm{N}$ & $106^{\circ} 13.2^{\prime} \mathrm{W}$ & 697 & & & \\
\hline Hell Creek & $47^{\circ} 35.3^{\prime} \mathrm{N}$ & $106^{\circ} 54.8^{\prime} \mathrm{W}$ & 710 & & & \\
\hline WYOMING & & & & Lovell, Big Horn Co., WY & 7.00 & 177 \\
\hline Bighorn River & $44^{\circ} 29.3^{\prime} \mathrm{N}$ & $108^{\circ} 02.9^{\prime} \mathrm{W}$ & 1155 & & & \\
\hline Shoshone River & $44^{\circ} 51.3^{\prime} \mathrm{N}$ & $108^{\circ} 19.8^{\prime} \mathrm{W}$ & 1169 & & & \\
\hline Unnamed Creek & $44^{\circ} 41.2^{\prime} \mathrm{N}$ & $108^{\circ} 04.4^{\prime} \mathrm{W}$ & 1331 & & & \\
\hline UTAH & & & & Dewey, Grand Co., UT & 12.11 & 209 \\
\hline Green River & $39^{\circ} 11.5^{\prime} \mathrm{N}$ & $110^{\circ} 04.6^{\prime} \mathrm{W}$ & 1245 & & & \\
\hline Price River & $39^{\circ} 14.3^{\prime} \mathrm{N}$ & $110^{\circ} 15.2^{\prime} \mathrm{W}$ & 1410 & & & \\
\hline Price River & $39^{\circ} 27.0^{\prime} \mathrm{N}$ & $110^{\circ} 37.7^{\prime} \mathrm{W}$ & 1450 & & & \\
\hline NEVADA & & & & Valley of Fire State Park, NV & 20.5 & 354 \\
\hline Virgin River & $36^{\circ} 47.4^{\prime} \mathrm{N}$ & $114^{\circ} 05.8^{\prime} \mathrm{W}$ & 517 & & & \\
\hline Virgin River & $36^{\circ} 50.4^{\prime} \mathrm{N}$ & $113^{\circ} 59.0^{\prime} \mathrm{W}$ & 528 & & & \\
\hline Virgin River & $36^{\circ} 53.8^{\prime} \mathrm{N}$ & $113^{\circ} 55.1^{\prime} \mathrm{W}$ & 546 & & & \\
\hline ARIZONA & & & & Buckeye, Maricopa Co., AZ & 21.9 & 344 \\
\hline Gila River & $33^{\circ} 20.5^{\prime} \mathrm{N}$ & $112^{\circ} 37.5^{\prime} \mathrm{W}$ & 271 & & & \\
\hline Gila River & $33^{\circ} 22.7^{\prime} \mathrm{N}$ & $112^{\circ} 19.5^{\prime} \mathrm{W}$ & 274 & & & \\
\hline Gila River & $33^{\circ} 15.2^{\prime} \mathrm{N}$ & $112^{\circ} 09.7^{\prime} \mathrm{W}$ & 280 & & & \\
\hline
\end{tabular}

presence (although in variable quantities) of saltcedar in discrete patches, relative cover of saltcedar was usually higher at all stand ages than cottonwood or willow. Saltcedar relative cover values varied between $1(<5 \%)$ and 5 $(>65 \%-85 \%)$ in younger stands $(<10$ years $)$ and between 5 and $7(>95 \%)$ in older stands $(>20$ years). Relative covers of cottonwood and willow declined over time, varying between 1 and 5 in younger stands and between $0(0 \%)$ and $4(35 \%-65 \%)$ in older stands (Fig. 3B).

\section{Soils}

Soil EC and texture did not change with saltcedar stand age (Table 3). However, pH decreased with increasing stand age $\left(r^{2}=\right.$ 0.450, $P<0.001$; Table 3, Fig. 4). To check for river of origin substrate bias, we subsampled data from the entire data set such that all stand ages were equally represented in each watershed. Subsampled data showed the same trend (Spearman correlation: $r_{s}=-0.520, P=0.020$, $n=19$ ), indicating that differences in soil $\mathrm{pH}$ over time were not driven by watershed-specific factors.

\section{Stem Growth}

Saltcedar stem growth was greatest in the southernmost region (Arizona; Fig. 5), although growth rates were not significant among regions (Table 4), i.e., no significant interaction of state $\times$ stem age was found. Sandbar willow stem growth rates did not differ among regions (Fig. 5 , Table 4). Stem growth of both species decreased inversely with elevation (Table 4 , bottom section). There was no significant interaction of elevation $\times$ species.

\section{Discussion}

While the introduction of saltcedar in central eastern Montana is recent ( $<40$ years), saltcedar populations are now present on most rivers. This increase appears to be due to multiple human introductions and dispersal. Recent searches for saltcedar in eastern Montana have added to initial reports by Robinson (1965) and Swenson et al. (1982). The species has been found on most river watersheds (8 of 10 in this region), with extensive naturalized stands on the Clark's Fork, Yellowstone, Bighorn, Little Bighorn, Musselshell, Powder, and Yellowstone Rivers (Sexton 2000, Lesica and Miles 2001, Pearce and Smith 2003), and isolated plants on the Milk and Tongue Rivers (Sexton 2000, Pearce and Smith 2003). There are no records on the Little Missouri and Poplar Rivers. The spread of saltcedar in this region appears as a 


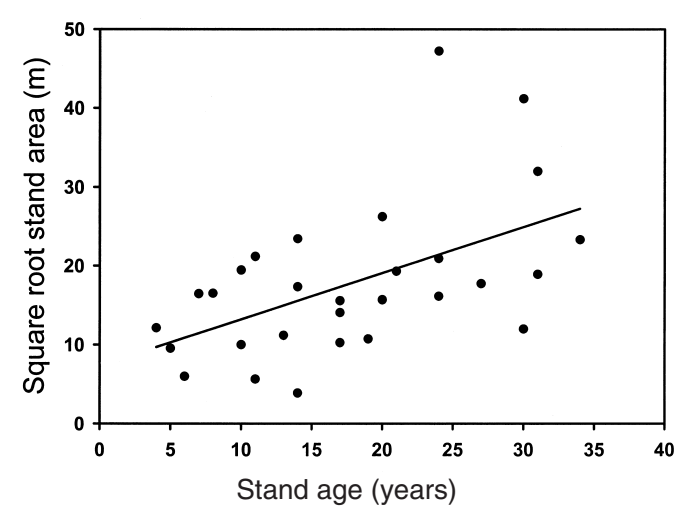

Fig. 2. Saltcedar stand area as a function of stand age in central eastern Montana study stands. Area was square-root transformed to increase homoscedasticity. Regression equation: $\mathrm{y}=0.59 \mathrm{x}+7.35 ; r^{2}=0.276, P=0.003, n=29$.

scattered or "satellite" pattern (Bazzaz 1986), as opposed to a continuous spread from an initial entry point. Humans are apparently aiding this jump dispersal via ornamental plantings (Pearce and Smith 2003). While the oldest stands were found on the Bighorn River, stands older than 30 years occurred on the Powder and Yellowstone Rivers (Fig. 1) and are reported north at Fort Peck Lake (Pearce and Smith 2003). We note that stand ages are likely underestimates, as stand-pioneering saltcedars may have died or been intentionally removed before we sampled. Additionally, failed saltcedar patches would go unnoticed.

The positive correlation between stand age and elevation on the Bighorn River suggests downstream spread within that watershed. No such correlations were found in stands on the Yellowstone and Powder Rivers (Fig. 1), suggesting multiple sites of introduction and/or upstream spread via wind dispersal. On the Powder River, stand ages decreased with distance from a site near Powderville (site PRF; Table 1, Fig. 1), indicating a possible site of introduction and upstream and downstream dispersal. Saltcedars as old as 51 years in 1997 were found upriver from the Yellowtail Dam (Wyoming, Bighorn River; Table 2) in Wyoming, suggesting downstream dispersal to the Bighorn River from older populations.

\section{Stand Persistence and Expansion}

The regional spread of saltcedar in Montana may be enhanced by anthropogenic effects
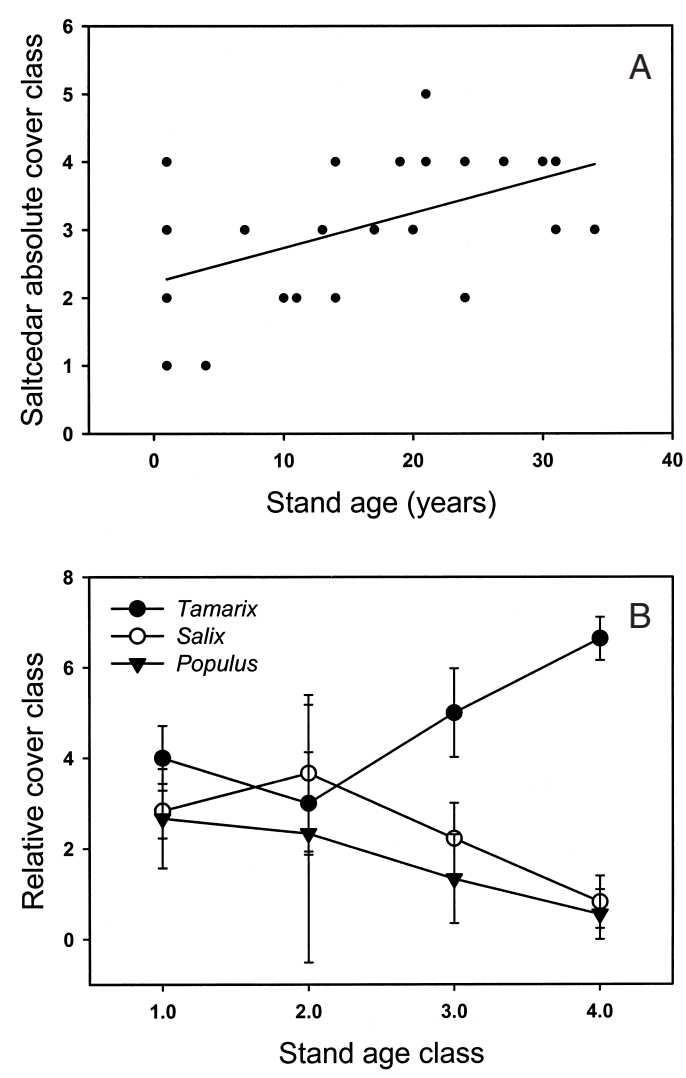

Fig. 3. A, Saltcedar absolute cover as a function of stand age in central eastern Montana study stands. Regression equation: $\mathrm{y}=0.051 \mathrm{x}+2.224 ; r^{2}=0.291, P=0.003, n=$ 29. B, Mean relative cover class $(1<5 \%, 25 \%-15 \%, 315 \%$ $35 \%, 435 \%-65 \%, 5$ 65\%-85\%, 6 85\%-95\%, $7>95 \%$ ) versus stand age class ( $\boldsymbol{I}$ saltcedar seedling beds, $2 \leq 10$ years, $311-20$ years, $4>20$ years) in study stands. Bars represent $95 \%$ confidence intervals.

such as altered flood cycles (Smith et al. 1998, Stromberg 1998b) and grazing (Pearce and Smith 2003, Lesica and Miles 2004). While we do not have a quantitative assessment, a large fraction of stands occurred at sites with anthropogenic disturbances such as grazing and clearing for improvements and diversions. The discrete nature of saltcedar patches in Montana likely denotes an affinity for such disturbances, which often produce introductions with noncontinuous distributions (Bazzaz 1986). Study sites were within sight of roads and may all share a common history of high human disturbance, differing from remote sites. Hence, our results could be biased since we sampled only road-accessible sites. However, $15 \%$ of study stands occurred on river channel islands, 
TABLE 3. Soils values and regression coefficients $\left(r^{2}\right)$ with stand age in riparian stands $(n=29)$ of saltcedar in central eastern Montana.

\begin{tabular}{lccc}
\hline Variable & Mean $\pm \mathrm{s}$ & Range & $r^{2}$ \\
\hline Electrical conductivity $(\mu \mathrm{S})$ & $992.1 \pm 1447.7$ & $115.0-6716.7$ & 0.003 \\
Sand $(\%)$ & $47.8 \pm 20.8$ & $7.8-88.0$ & 0.001 \\
Silt $(\%)$ & $34.9 \pm 15.4$ & $7.0-66.5$ & 0.028 \\
Clay $(\%)$ & $17.2 \pm 8.9$ & $4.5-42.0$ & 0.052 \\
$\mathrm{pH}$ & $7.6 \pm 0.32$ & $6.98-8.35$ & $0.450^{\mathrm{a}}$ \\
\hline
\end{tabular}

ap $<0.001$

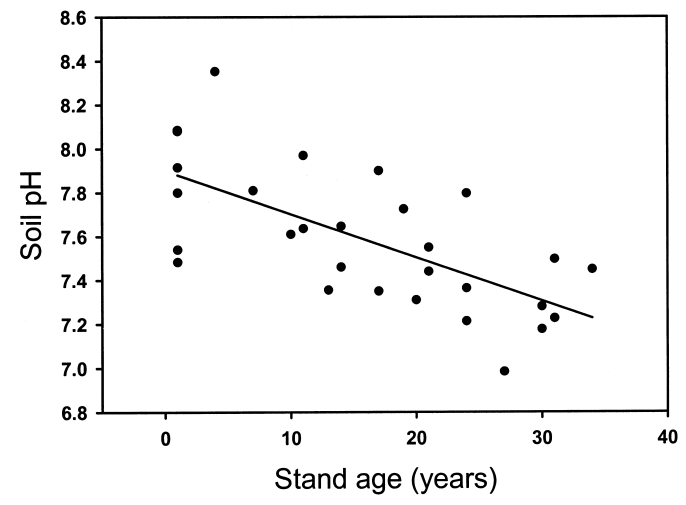

Fig. 4. Soil $\mathrm{pH}$ as a function of stand age in central eastern Montana study stands. Regression equation: $\mathrm{y}=-0.02 \mathrm{x}+$ $7.90 ; r^{2}=0.450, P<0.001, n=29$.

where grazing and clearing disturbances are reduced, and on undammed river stretches, where flood cycles are less perturbed, suggesting that saltcedar spread may also occur in reaches with lower anthropogenic disturbances.

The positive relationship between saltcedar stand age and area suggests that patches are expanding as well as persisting over time. Although saltcedar often grows in even-aged stands from seedbed-forming flood events (Shafroth et al. 1998, Shafroth et al. 2002), several saltcedar stands in Montana had mixed demographics (seedlings among adult plants). The largest saltcedar stand surveyed (Myers Bridge, Yellowstone River; 23 years old) also had the highest seedling density (>3500 seedlings $\cdot \mathrm{m}^{-2}$ ). If seedlings rely on new sedimentation, this finding suggests that sediment deposition (via flood events) can occur within established saltcedar stands and that new seedlings can recruit successfully beneath conspecifics. In addition to this sexual recruitment, we observed young suckers ( $<3$ years) sprouting abundantly in older stands. Hence, it appears that saltcedar stands can increase in area by both sexual and vegetative means after initial flood-related establishment events. These results are correlative, and the possibility exists that the oldest stands represent large colonization patches that have remained large over time (e.g., a decrease in the mean magnitude of recruitment floods over time could cause successively smaller patches). Alternatively, stands may expand from coalescing geomorphic surfaces (i.e., multiple sandbars may form into one larger bar following subsequent flooding and sediment deposition). The observed increase in saltcedar absolute cover with stand age is also correlative but suggests that either cover increases with time or that only young stands with high saltcedar absolute cover are able to persist over time. Older stands may be a source of higher seed production if cover and seed production covary.

\section{Vegetation and Soils}

Our results suggest that saltcedar established and persisted where woody natives were not abundant. This is consistent with the measured low competitive ability of saltcedar seedlings (Sher and Marshall 2003) and the hypothesis that saltcedar establishment depends on disturbances unfavorable to natives (Busch and Smith 1995, Shafroth et al. 1998, Shafroth et al. 2002). Although saltcedar in Montana experience diminished growth beneath mature cottonwood stands (Lesica and Miles 2001), our results suggest that once saltcedar stands establish, they are unlikely to shift to stands of native vegetation within the observed age span ( $<35$ years).

Little is known about long-term successional processes in saltcedar stands (Everitt 1998, Stromberg 1998a). Populus and Salix seedlings were occasionally encountered beneath mature saltcedar stands, although in low 

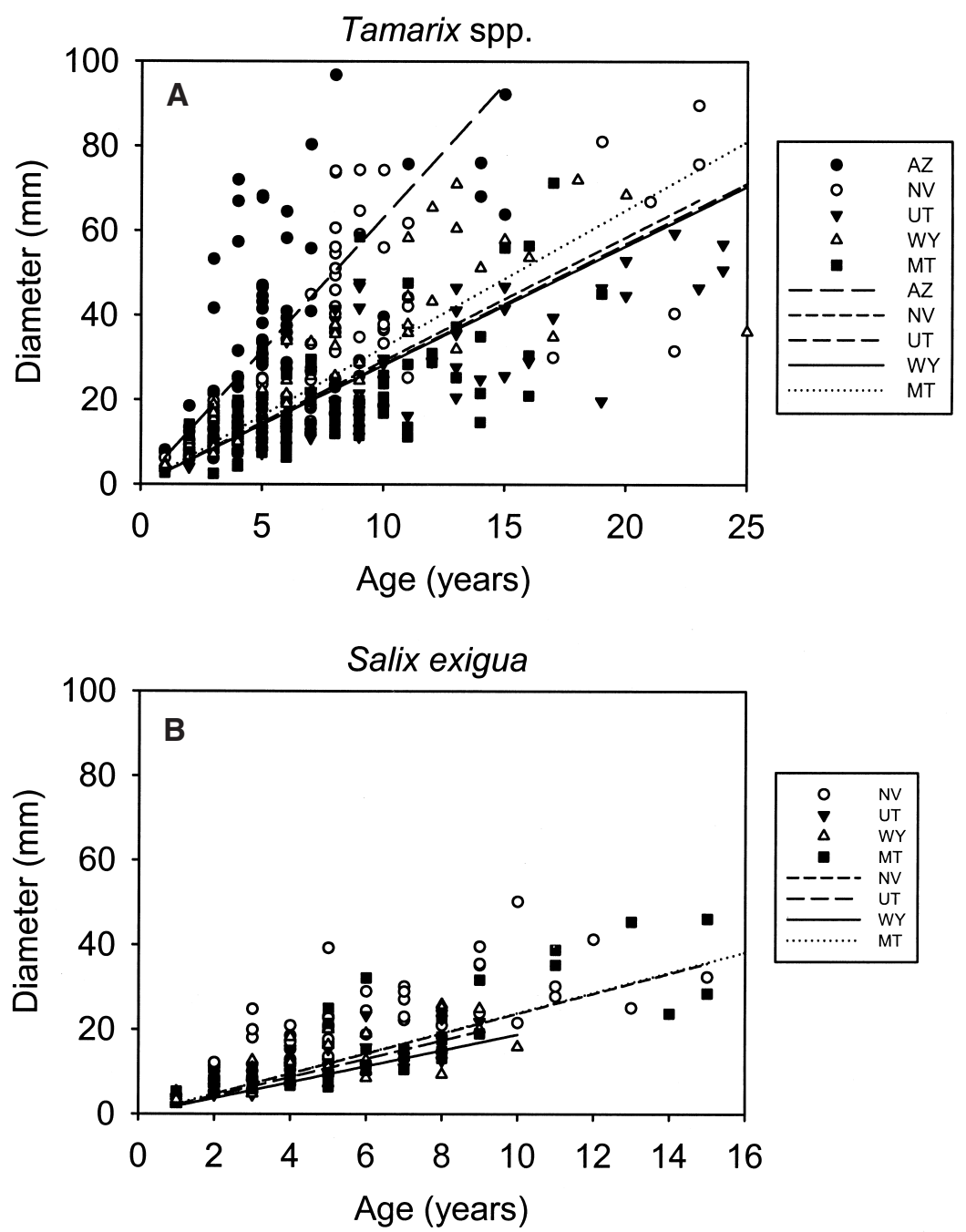

Fig. 5. Saltcedar (A) and sandbar willow (B) stem growth rates illustrated as regressions of stem age vs. stem diameter, with the $y$-intercept set to 0 (forced through the origin), along a latitudinal gradient in the western United States. AZ = Arizona, NV = Nevada, UT $=$ Utah, $\mathrm{WY}=$ Wyoming, $\mathrm{MT}=$ Montana.

densities. Native phreatophytes (e.g., Populus) may not be able to establish on alluvium deposited beneath mature saltcedar. Decreases in native woody plants with increases of saltcedar are often correlated (Busch and Smith 1995), but the cause is difficult to identify and may include complex interacting factors such as altered flood cycles, drawdown, and humancaused disturbances (Sala et al. 1996, Cleverly et al. 1997, Shafroth et al. 2000, 2002).

In the Southwest saltcedar is hypothesized to generate or associate with higher soil salinity (Busch and Smith 1993, Smith et al. 1998), although comparisons between similar river sites with and without saltcedar have lacked evidence for this (Stromberg 1998b). We found no relationship between surface $(0-7.5 \mathrm{~cm})$ soil salinity and stand age, although we did observe a decrease of soil $\mathrm{pH}$ in older stands (decreasing to 7.0). This is consistent with general patterns of aging soils (Helyar and Porter 1989) and may be an effect of increasing organic inputs over time in the sandstone and shale soils (Alt and Hyndman 1986) of eastern Montana. Busch and Smith (1995) reported $\mathrm{pH}$ values that varied unpredictably 
TABLE 4. Summary of analysis of variance for stem growth of Tamarix spp. (saltcedar) and Salix exigua (sandbar willow) stems among regions and elevations. Results below are from 3 separate ANOVAs. In the first 2 ANOVAs (Saltcedar, Willow), stem diameter was the dependent variable, stem age a covariate, and state of origin (region) the independent variable. For saltcedar, $n=401$ stem samples ( 88 for Arizona, 76 for Nevada, 79 for Utah, 78 for Wyoming, 80 for Montana). For willow, $n=186$ stem samples (56 for Nevada, 32 for Utah, 48 for Wyoming, 50 for Montana). In the 3rd ANOVA (All stems), saltcedar stems from Arizona were not included. Stem diameter/age was the dependent variable, elevation a covariate, and species the independent variable. For saltcedar and willow $n=313$ and 186, respectively. All noncategorical variables were log transformed.

\begin{tabular}{|c|c|c|c|c|c|}
\hline ANOVA & SS & df & MS & $F$-ratio & Significance \\
\hline \multicolumn{6}{|l|}{ SALTCEDAR } \\
\hline Stem age & 25.634 & 1 & 25.634 & 776.599 & 0.001 \\
\hline Region & 0.476 & 4 & 0.119 & 3.607 & 0.007 \\
\hline Region $\times$ Stem age & 0.198 & 4 & 0.050 & 1.500 & 0.201 \\
\hline \multicolumn{6}{|l|}{ WILLOW } \\
\hline Stem age & 6.878 & 1 & 6.878 & 345.851 & 0.001 \\
\hline Region & 0.158 & 3 & 0.053 & 2.645 & 0.051 \\
\hline Region $\times$ Stem age & 0.019 & 3 & 0.006 & 0.324 & 0.808 \\
\hline \multicolumn{6}{|l|}{ ALL STEMS } \\
\hline Species & 0.092 & 1 & 0.092 & 2.578 & 0.109 \\
\hline Elevation & 2.416 & 1 & 2.416 & 67.709 & 0.001 \\
\hline Elevation $\times$ Species & 0.070 & 1 & 0.070 & 1.971 & 0.161 \\
\hline
\end{tabular}

among sites differing in saltcedar dominance. Soil acidification may be an artifact of longterm, natural successional changes occurring on sand bars where saltcedar populations initially recruit.

Contrary to the findings of Stromberg (1998b), we found no increase in surface clay content or other changes in soil texture in older saltcedar stands. A weakness of this study is that we did not examine soils beneath native stands free from saltcedar. Such comparisons are needed to understand saltcedar-specific effects.

\section{Stem Growth Across Climate and Latitude}

Consistent with the decrease of saltcedar seedling growth rates under low temperature (Sexton et al. 2002), we found a decrease in stem growth rates in adult plants (including sandbar willow) at higher elevations, which also have colder climates (Table 2). Saltcedar and sandbar willow did not differ from each other in stem growth responses to elevation, indicating similar growth responses to climate. Climate does not vary linearly with latitude among sites sampled in this study. Hence, despite potential site condition effects (Haigh 1998), latitude was not a reliable predictor of abiotic constraint on stem growth. We observed no significant difference in stem growth rates among regions for either species, although the highest growth rate found was for saltcedar in southern Arizona, the lowest latitude and elevation in the study (Table 2, Fig. 5). Stem growth rates are used here as indicators of the growth potential of discrete recruitment units, but they are not necessarily indicators of whole-plant growth and productivity, which is related to survival and fitness of mature individuals (Aarssen and Keogh 2002). Differences in biomass allocation, height, and stem mortality along the latitudinal gradient (i.e., fewer, larger stems in southern populations versus many, smaller stems in northern populations [Sexton 2000]) may offset individual stem growth rates such that whole-plant productivity and plant size are reduced in colder climates. However, because stems are discrete sexual reproductive units, their sustained growth across a wide latitudinal range suggests sustained sexual reproductive potential.

\section{Conclusion}

Results from this study show an increase of saltcedar in central eastern Montana. Saltcedar stands are present in most major riparian corridors and are able to persist and increase in size over time. Our results also suggest that saltcedar establishes at sites with low cover of native species and that, over time, woody natives within saltcedar stands do not increase in 
cover and displace saltcedar. These results suggest that saltcedar has the potential to spread in the North and, as a consequence, reduce establishment area for native phreatophytes as well as change the functional character of wetlands they inhabit. We recommend proactive approaches, such as managing for native phreatophytes (Lesica and Miles 2001, 2004) and measures outlined in Pearce and Smith (2003) and Stromberg (2001), to diminish saltcedar's spread in the Great Plains. Habitats of the Great Plains with climates similar to central eastern Montana may expect saltcedar to spread, regardless of latitude, in the presence of suitable recruitment sites.

Future research is needed to understand the functional differences between habitats with and without saltcedar in marginal climates where stands persist long-term. Direct observation of recruiting populations (e.g., abundance, mortality, or genetic data) at distributional margins would allow a clearer understanding of the mechanisms and rate of spread.

\section{ACKNOWLEDGMENTS}

This research was supported by a Noxious Weed Trust Fund (Montana Department of Agriculture) grant to A.S. and K.M., and grants from the NSF-MONTS and the UM Grant Programs to A.S. The Biological Invasions IGERT at UC Davis (NSF-DGE 0114432) provided graduate funding to J.P.S. during manuscript preparation. We thank Roger Sheley, Vince Thomas, Diana Cooksey, Bill NuMiller, Brad Cook, and Marko Manukian for their assistance in locating study sites. Vince Thomas and the Rosebud Weed District made valuable logistical contributions and provided a flight over the Yellowstone River to assess saltcedar spread there. Traycee Bowerman and Lauren Quinn provided indispensable assistance in the field. Peter Lesica and Steve Shelly provided assistance with plant identifications, and Wes Niles provided plant collection materials. Thomas DeLuca provided laboratory space, equipment, and much expertise with soil methods. We kindly thank Ragan Callaway, Thomas DeLuca, Cheryl Pearce, Peter Lesica, Michael Barbour, John McKay, Carole Hom, and 2 anonymous reviewers for their helpful comments. Special thanks goes to Monique Kolster for editorial advice, assistance with Fig. 1, and her endless support during this project.

\section{Literature Cited}

Aarssen, L.W., And T. KeOGH. 2002. Conundrums of competitive ability in plants: what to measure? Oikos 96:531-542.

Alt, D., And D.W. Hyndman. 1986. Roadside geology of Montana. Mountain Press, Missoula, MT.

BAuM, B.R. 1978. The genus Tamarix. Israel Academy of Sciences and Humanities, Jerusalem.

BAZZAZ, F.A. 1986. Life history of colonizing plants: some demographic, genetic, and physiological features. Pages 96-110 in H.A. Mooney and J.A. Drake, editors, Ecology of biological invasions of North America and Hawaii. Springer-Verlag, New York.

Brock, J.H. 1994. Tamarix spp. (salt cedar), an invasive exotic woody plant in arid and semi-arid riparian habitats of western USA. Pages 27-44 in L.C. De Waal, L.E. Child, P.M. Wade, and J.H. Brock, editors, Ecology and management of invasive riverside plants. Wiley and Sons, New York.

Buckman, H.O., and N.C. Brady. 1969. The nature and properties of soils. The Macmillan Company, Toronto, Ontario.

Busch, D.E., AND S.D. Smith. 1993. Effects of fire on water and salinity relations of riparian woody taxa. Oecologia (Heidelberg) 94:186-194.

1995. Mechanisms associated with decline of woody species in riparian ecosystems of the southwestern U.S. Ecological Monographs 65:347-370.

Cleverly, J.R., S.D. Smith, A. Sala, and D.A. DevitT. 1997. Invasive capacity of Tamarix ramosissima in a Mojave Desert floodplain: the role of drought. Oecologia, Berlin 111:12-18.

Dixon, M.D., AND W.C. Johnson. 1999. Riparian vegetation along the Middle Snake River, Idaho: zonation, geographical trends, and historical changes. Great Basin Naturalist 59:18-34.

EveritT, B.L. 1998. Chronology of the spread of tamarisk in the central Rio Grande. Wetlands 18:658-668.

Garoogian, D., EDitor. 2001. Weather America: a thirtyyear summary of statistical weather data and rankings. 2nd edition. Grey House Publishing, Lakeville, CT.

Gaskin, J.F., AND B.A. SCHAAL. 2002. Hybrid Tamarix widespread in U.S. invasion and undetected in native Asian range. Proceedings of the National Academy of Sciences of the United States of America 99: 11256-11259.

GeE, G.W., AND J.W. Bauder. 1986. Particle-size analysis. In: A. Klute, editor, Methods of soil analysis: part 1. Physical and mineralogical methods. Soil Science Society of America, Madison, WI.

Haigh, S.L. 1998. Stem diameter-age relationships of Tamarix ramosissima on lake shore and stream sites in southern Nevada. Southwestern Naturalist 43: $425-429$.

Helyar, K.R., AND W.M. Porter. 1989. Soil acidification, its measurement and the processes involved. Pages 61-101 in A. D. Robson, editor, Soil acidity and plant growth. Academic Press, San Diego, CA.

Kennedy, T.A., And S.E. HobBiE. 2004. Saltcedar (Tamarix ramosissima) invasion alters organic matter dynamics in a desert stream. Freshwater Biology 49:65-76.

LesicA, P., AND S. Miles. 2001. Tamarisk growth at the northern margin of its naturalized range in Montana, USA. Wetlands 21:240-246. 
2004. Ecological strategies for managing tamarisk on the C.M. Russell National Wildlife Refuge, Montana, USA. Biological Conservation 119:535-543.

Pearce, C.M., AND D.G. Smith. 2003. Saltcedar: distribution, abundance, and dispersal mechanisms, northern Montana, USA. Wetlands 23:215-228.

Robinson, T.W. 1965. Introduction, spread and areal extent of saltcedar (Tamarix) in the western states. U.S. Geological Survey, Reston, VA.

Sala, A., S.D. Smith, and D.A. DevitT. 1996. Water use by Tamarix ramosissima and associated phreatophytes in a Mojave Desert floodplain. Ecological Applications 6:888-898.

Sexton, J.P. 2000. Invasive potential of Tamarix ramosissima (saltcedar) in continental climates of North America. Master's thesis, University of Montana, Missoula.

Sexton, J.P., J.K. McKay, and A. Sala. 2002. Plasticity and genetic diversity may allow saltcedar to invade cold climates in North America. Ecological Applications 12:1652-1660.

Shafroth, P.B., G.T. Auble, J.C. Stromberg, and D.T. Patten. 1998. Establishment of woody riparian vegetation in relation to annual patterns of streamflow, Bill Williams River, Arizona. Wetlands 18:577-590.

Shafroth, P.B., J.C. Stromberg, and D.T. Patten. 2000. Woody riparian vegetation response to different alluvial water table regimes. Western North American Naturalist 60:66-76.

2002. Riparian vegetation response to altered disturbance and stress regimes. Ecological Applications 12:107-123.

Sher, A.A., AND D.L. Marshall. 2003. Seedling competition between native Populus deltoides (Salicaceae) and exotic Tamarix ramosissima (Tamaricaceae) across water regimes and substrate types. American Journal of Botany 90:413-422.
Sher, A.A., D.L. Marshall, AND J.P. TAYLOR. 2002. Establishment patterns of native Populus and Salix in the presence of invasive nonnative Tamarix. Ecological Applications 12:760-772.

Smith, S.D., D.A. Devitt, A. Sala, J.R. Cleverly, and D.E. Busch. 1998. Water relations of riparian plants from warm desert regions. Wetlands 18:687-696.

SOKAL, R.R., AND J.F. RoHLF. 1995. Biometry. 3rd edition. W.H. Freeman and Company, New York.

StromberG, J.C. 1998a. Dynamics of Fremont cottonwood (Populus fremontii) and saltcedar (Tamarix chinensis) populations along the San Pedro River, Arizona. Journal of Arid Environments 40:133-155.

.1998b. Functional equivalency of saltcedar (Tamarix chinensis) and Fremont cottonwood (Populus fremontii) along a free-flowing river. Wetlands 18: 675-686.

. 2001. Restoration of riparian vegetation in the south-western United States: importance of flow regimes and fluvial dynamism. Journal of Arid Environments 49:17-34.

Swenson, J.E., P. Hendricks, And A. Farjon. 1982. Arrival and occurrence of Tamarix chinensis (tamarisk) along the Yellowstone River in Treasure and Rosebud Counties, Montana. Proceedings of the Montana Academy of Sciences 41:67-70.

Sykes, M.T., I.C. Prentice, and W. Cramer. 1996. A bioclimatic model for the potential distributions of north European tree species under present and future climates. Journal of Biogeography 23:203-233.

USDA AND NRCS. 2004. The PLANTS database, version 3.5. National Plant Data Center, Baton Rouge, LA. Available from: http://plants.usda.gov

Received 22 April 2004 Accepted 23 February 2005 